\title{
WYSTĄPIENIA SEJMOWE PREMIERA WŁADYSŁAWA GRABSKIEGO I MINISTRÓW JEGO DRUGIEGO RZĄDU W DEBATACH NAD PROJEKTAMI USTAW
}

\author{
Paweł Gofron \\ Uniwersytet Papieski Jana Pawła II w Krakowie
}

\begin{abstract}
THE SEJM SPEECHES OF PRIME MINISTER WŁADYSŁAW GRABSKI AND MINISTERS OF HIS SECOND GOVERNMENT DURING THE DEBATES OVER DRAFT LAWS
\end{abstract}

This article presents the Sejm speeches of prime minister Władysław Grabski and ministers of his second government during the debates over draft laws. The text consists of three parts. In the first section, all speeches delivered by members of the Council of Ministers in the Second Polish Republic's Sejm of the first term were analysed. This review made it possible to present the relevant statistical information. In the second section, the work of Prime Minister Grabski and his ministers in the Sejm (especially in the context of the reform of the State Treasury) was reconstructed. The third section of the article outlines the participation of the government's members in the legislative processes initiated by the deputies and clubs of deputies.

Key words: Władysław Grabski, the second government of Władysław Grabski, the Second Polish Republic's Sejm of the first term, Sejm speeches, Sejm debates.

Słowa kluczowe: Władysław Grabski, drugi rząd Władysława Grabskiego, Sejm II Rzeczypospolitej I kadencji, wystąpienia sejmowe, debaty sejmowe.

Drugi rząd Władysława Grabskiego zapisał się na kartach historii II Rzeczypospolitej przede wszystkim za sprawą przeprowadzonych pod jego kierunkiem głębokich reform społecznych, gospodarczych i walutowych, których podstawowym celem było dążenie do uzyskania i utrzymania równowagi budżetowej, wprowadzenie nowej waluty i zwalczenie hiperinflacji. Gabinet ten, powołany 19 grudnia 
1923 roku (bezpośrednio po upadku „chjeno-piastowskiego” gabinetu Wincentego Witosa i nieudanej próbie utworzenia rządu przez Stanisława Thugutta) ${ }^{1}$, składał się z 12 ministerstw ${ }^{2}$, na czele których stanęło 11 ministrów oraz sam Grabski jako premier i równocześnie minister skarbu ${ }^{3}$.

Niniejszy artykuł stawia sobie za cel przeanalizowanie wystąpień sejmowych członków pozaparlamentarnej Rady Ministrów z Grabskim na czele w debatach nad projektami ustaw. Podjęcie tego rodzaju tematu, opisującego nie tylko model relacji między władzą wykonawczą a ustawodawczą, ale również przebieg poszczególnych uzgodnień dotyczących kształtu regulacji prawnych ważnych dla rządu (procedowanych bowiem $\mathrm{z}$ udziałem jego przedstawicieli), wydaje się zasadne w kontekście uzupełnienia bogatej literatury dotyczącej omawianego gabinetu i przeprowadzonych przezeń reform gospodarczych ${ }^{4}$.

Zgodnie z Regulaminem obrad Sejmu II Rzeczypospolitej I kadencji marszałek tej izby zobowiązany był do udzielenia głosu premierowi i ministrom, którzy uczestniczyli w posiedzeniu i wyrazili taką chęć. Na mocy art. 47 przysługiwał im przywilej przemawiania poza ustaloną kolejnością mówców i bez ograniczeń czasowych

${ }^{1}$ A. Ajnenkiel, Od rzadów ludowych do przewrotu majowego. Zarys dziejów politycznych Polski 1918-1926, Warszawa 1977, s. 331-333; J. Jakie1, Gabinet Wtadystawa Grabskiego. 19 XII 1923-13 XI 1925 [w:] Gabinety Drugiej Rzeczypospolitej, red. J. Fary ś, J. Paj e w s ki, Szczecin-Poznań 1991, s. 123 i n.

${ }^{2}$ Utworzenie przez Grabskiego dwunastu ministerstw nie było przypadkiem. W pierwotnej fazie tworzenia rządu musiał on bowiem powołać się na strukturę wcześniejszego rządu, gdyż poszczególne resorty tworzone i usuwane były na podstawie ustawy. Chcąc zwiększyć bądź ograniczyć liczbę ministerstw, mógł to uczynić dopiero po zaprzysiężeniu, wnosząc do sejmu projekt stosownych uregulowań. M. Pi etrzak, Rzady parlamentarne w Polsce w latach 1919-1926, Warszawa 1969, s. 163.

${ }^{3}$ Drugi gabinet Władysława Grabskiego miał charakter pozaparlamentarny. Nowy premier konstruował oblicze polityczne swojego rządu w taki sposób, aby zadowolić zarówno prawicę (powołanie na ministra spraw zagranicznych Maurycego Zamoyskiego), jak i lewicę (nominacja ministerialna dla Kazimierza Sosnkowskiego). Szczegółowy skład rządu wraz z wykazem ministrów i kierowników ministerstw oraz okresami sprawowania przezeń funkcji zob. Ministrowie gabinetów Polski Niepodleglej. 19 XII 1923-14 XI 1925 [w:] Ministrowie Polski Niepodlegtej 1918-1945, red. M. B a umgart, H. Walc zak, A. W ąt or, Szczecin 2001, s. 25 i n.

${ }^{4}$ Spośród licznych biografii Władysława Grabskiego i publikacji opisujących zainicjowane przez niego reformy na uwagę zasługują następujące pozycje książkowe i artykuły w pracach zbiorowych: M.M. Drozdowski, Władystaw Grabski, Rzeszów-Warszawa 2004; W. Morawski, Władysław Grabski - polityk, mą̇ stanu, reformator, Warszawa 2004; W. Moraw ski, Władystaw Grabski, premier rządu polskiego 23 VI-24 VII 1920, 19 XII 1923-14 XI 1925 [w:] Prezydenci i premierzy Drugiej Rzeczypospolitej, red. A. Chojnowski, P. Wróbe1, Wrocław 1992, s. 121-134; J. Jakie1, Grabski Władystaw [w:] Ministrowie Polski Niepodległej 1918-1945, op. cit., s. 124-129; J. Goł ę bi o w sk i, Grabski Władystaw [w:] Kto byt kim w Drugiej Rzeczypospolitej, red. J.M. Maj c hrow s ki, Warszawa 1994, s. 40; K. Piwarski, Grabski Władystaw (1874-1938) [w:] Polski Stownik Biograficzny, t. 8, red. K. Le p s zy, Wrocław 1960, s. 524-528; A. F ro n c ze k-K w a r ta, Polityka finansowa i gospodarcza rządu Władysława Grabskiego w okresie reformy walutowo-skarbowej (1923-1925), Poznań 2014; J. S k odlars ki, Władysław Grabski jako ekonomista (1874-1938), Łódź 2015. Oceny działań drugiego rządu Grabskiego pozostają w opinii badaczy i historyków dość niejednoznaczne - począwszy od opinii w pełni pozytywnych, uznających wielką wagę przeprowadzonych przezeń reform, a skończywszy na głosach krytycznych, które zarzucają premierowi przesadny fiskalizm, hamujący rozwój sektora prywatnego. 
dotyczących długości trwania wypowiedzi ${ }^{5}$. Inne zapisy przywołanego Regulaminu stanowiły, że przewodniczący obradom marszałek dysponował prawem do przywołania przedstawiciela rządu „do rzeczy” (jeśli jego mowa nie dotyczyła przedmiotu obrad) lub „do porządku” (jeśli jego zachowanie powodowało zakłócenie przebiegu obrad albo też nie odpowiadało godności izby poselskiej) ${ }^{6}$.

Mając to na uwadze, słuszne zdaje się przeanalizowanie, w procedowaniu których ustaw czynny udział brał premier Grabski i ministrowie wchodzący w skład jego drugiego rządu. Jakie sprawy rozstrzygane na forum sejmu - obok ekonomiczno-gospodarczych kierunków reform - zwróciły uwagę członków tego gabinetu? Jak często korzystali oni z możliwości zabierania głosu podczas obrad? Czy ministrowie odnosili się zarówno do rządowych, jak i poselskich projektów ustaw? Jaki wreszcie charakter miały tego rodzaju wystąpienia - merytoryczny czy może polemiczny?

$\mathrm{W}$ odpowiedzi na powyższe pytania odnotować należy, że w okresie drugiego premierostwa Władysława Grabskiego z prawa do zabierania głosu w trakcie obrad Sejmu II Rzeczypospolitej I kadencji premier i członkowie jego gabinetu skorzystali łącznie 151 razy. W tym miejscu należy poczynić istotną uwagę, że omawiany rząd, odpowiednio w styczniu i lipcu 1924 roku, otrzymał dwukrotnie w drodze ustawowej tzw. pełnomocnictwa, które w ściśle zdefiniowanym przedziale czasowym dawały możliwość wydawania przez prezydenta na wniosek rządu (na podstawie uchwał Rady Ministrów) rozporządzeń z mocą ustawy w enumeratywnie wyliczonym zakresie. W konsekwencji wiele spraw przeprowadzanych było w ramach przyspieszonego procesu legislacyjnego, z pominięciem inicjowania debat nad projektami ustaw w parlamencie?

Dokładne dane dotyczące sejmowych mów premiera Grabskiego i jego ministrów zawiera tabela 1 . Uwzględniono w niej motywy rządowych wystąpień, począwszy od udziału w konkretnych procesach legislacyjnych (wystąpienia w ramach czytań projektów ustaw), poprzez debaty nad wnioskami poselskimi, a skończywszy na dyskusjach nad przedłożonymi przez posłów interpelacjami.

W związku z tym, że w okresie funkcjonowania drugiego rządu Grabskiego odbyło się 166 posiedzeń sejmu, można przyjąć, iż jedynie na co dziesiątym z nich w obradach nie brał czynnego udziału członek rzeczonego gabinetu. Należy jednak pamiętać, że wskaźnik ten ma jedynie charakter statystyczny. W wielu bowiem przypadkach $\mathrm{w}$ trakcie jednego dnia obrad sejmu zanotowano $\mathrm{w}$ stenogramie kilka rządowych przemówień. Dane zawarte w tabeli 1 obrazują ponadto, że spośród

${ }^{5}$ Sejm II RP, I kadencja [dalej: kad.], Regulamin obrad Sejmu uchwalony 16 II 1923, uzupełniony zgodnie z uchwałami Sejmu z dnia 11 X 1923, 30 XI 1923, 14 XI 1924 i 18 XII 1924 wraz ze skorowidzem rzeczowym do regulaminu i Konstytucją Rzeczypospolitej Polskiej, art. 47, https://bs.sejm.gov. pl/F? func=file\&file_name=find-nowe-2rp-sejm\&local_base=ars01 [dostęp: 20.02.2017]; W. Ko mar n ick i, Polskie prawo polityczne, Warszawa 2008, s. 323 i n.

${ }^{6}$ Sejm II RP, I kad., Regulamin..., art. 58, 60, 68.

${ }^{7}$ Szerzej o założeniach ustaw o pierwszych i drugich pełnomocnictwach wraz z przebiegiem debaty plenarnej poprzedzającej ich uchwalenie zob. P. G o fro on, Ustawy o nadzwyczajnych petnomocnictwach dla prezydenta Rzeczpospolitej w 1924 roku zob. O ksztalt Rzeczpospolitej. Studia z zakresu polskiej myśli politycznej i ustrojowej okresu międzywojennego, red. P. Go fron, A. Paderewska, A. Matuła, Kraków 2016, s. 145-160. 
wszystkich sejmowych wystąpień członków drugiego gabinetu Grabskiego dominowały mowy dotyczące bezpośrednio czytań projektów ustaw. Wśród nich zdecydowaną większość (90\%) stanowiły z kolei te, które odnosiły się do propozycji uregulowań prawnych wniesionych do sejmu przez premiera Grabskiego i członków jego Rady Ministrów oraz przez poprzednie gabinety.

Tabela 1. Wystąpienia członków drugiego gabinetu Władysława Grabskiego na forum Sejmu II Rzeczypospolitej I kadencji

\begin{tabular}{|c|c|c|c|}
\hline \multicolumn{4}{|c|}{$\begin{array}{c}\text { Lączna liczba wystąpień przedstawicieli drugiego rządu Wladysława Grabskiego } \\
\text { na forum sejmu }\end{array}$} \\
\hline \multicolumn{3}{|c|}{151} \\
\hline W tym w ramach czytania projektów ustaw & W tym w ramach pozostałych debat \\
\hline \multicolumn{3}{|c|}{121} & W tym w ramach \\
\hline $\begin{array}{c}\text { W tym w ramach } \\
\text { czytania rządowych } \\
\text { projektów ustaw }\end{array}$ & $\begin{array}{c}\text { Wytania poselskich } \\
\text { projektów ustaw }\end{array}$ & $\begin{array}{c}\text { nad wnioskami } \\
\text { poselskimi }\end{array}$ & $\begin{array}{c}\text { W tym ramach debat } \\
\text { nad interpelacjami } \\
\text { posłów }\end{array}$ \\
\hline 109 & 12 & 26 & 4 \\
\hline
\end{tabular}

Źródło: opracowanie własne na podstawie: Sejm II RP, I kad., Spr. Sten. 89. pos. z 20 XII 1923 - Spr. Sten. 254. pos. z 13 XI 1925.

Zgodnie z tematem niniejszego artykułu w dalszej jego części szczegółowo zaprezentowana zostanie ostatnia $\mathrm{z}$ wymienionych wyżej kategorii wypowiedzi. Poniższe zestawienie 109 wystąpień członków drugiego rządu Grabskiego z podziałem na resorty, w imieniu których zabierali oni głos, ma na celu uporządkowanie i zarazem kompleksowe ujęcie przedmiotowych treści.

Tabela 2. Wystąpienia członków drugiego gabinetu Władysława Grabskiego na forum Sejmu II Rzeczypospolitej I kadencji w ramach czytań rządowych projektów ustaw

\begin{tabular}{|c|c|c|c|c|}
\hline \multirow[t]{2}{*}{ Resort } & \multirow[t]{2}{*}{ Prelegent } & \multicolumn{3}{|c|}{$\begin{array}{l}\text { Liczba wystąpień w ramach czytań } \\
\text { rządowych projektów ustaw } \\
\text { wniesionych przez: }\end{array}$} \\
\hline & & $\begin{array}{l}\text { poprzednie } \\
\text { rządy }\end{array}$ & $\begin{array}{l}\text { drugi rząd } \\
\text { Grabskiego }\end{array}$ & ogółem \\
\hline \multirow{2}{*}{$\begin{array}{l}\text { Prezydium Rady } \\
\text { Ministrów }\end{array}$} & $\begin{array}{l}\text { premier i minister skarbu } \\
\text { Władysław Grabski }\end{array}$ & - & 19 & \multirow{2}{*}{20} \\
\hline & $\begin{array}{l}\text { podsekretarz stanu } \\
\text { Władysław Studziński }\end{array}$ & - & 1 & \\
\hline \multirow{3}{*}{ Ministerstwo Skarbu } & $\begin{array}{c}\text { wiceminister Bolesław } \\
\text { Markowski }\end{array}$ & 4 & 11 & \multirow{3}{*}{35} \\
\hline & $\begin{array}{c}\text { wiceminister Czesław } \\
\text { Klarner }\end{array}$ & 2 & 10 & \\
\hline & $\begin{array}{l}\text { dyrektor departamentu } \\
\text { Marian Głowacki }\end{array}$ & - & 8 & \\
\hline
\end{tabular}




\begin{tabular}{|c|c|c|c|c|}
\hline \multirow[t]{2}{*}{ Resort } & \multirow[t]{2}{*}{ Prelegent } & \multicolumn{3}{|c|}{$\begin{array}{l}\text { Liczba wystąpień w ramach czytań } \\
\text { rządowych projektów ustaw } \\
\text { wniesionych przez: }\end{array}$} \\
\hline & & $\begin{array}{l}\text { poprzednie } \\
\text { rządy }\end{array}$ & $\begin{array}{l}\text { drugi rząd } \\
\text { Grabskiego }\end{array}$ & ogółem \\
\hline \multirow{2}{*}{$\begin{array}{l}\text { Ministerstwo Spraw } \\
\text { Wewnętrznych }\end{array}$} & minister Zygmunt Hübner & - & 1 & \multirow{2}{*}{3} \\
\hline & minister Cyryl Ratajski & - & 2 & \\
\hline $\begin{array}{l}\text { Ministerstwo Spraw } \\
\text { Zagranicznych }\end{array}$ & $\begin{array}{l}\text { minister Aleksander } \\
\text { Skrzyński }\end{array}$ & - & 1 & 1 \\
\hline \multirow{3}{*}{$\begin{array}{l}\text { Ministerstwo Spraw } \\
\text { Wojskowych }\end{array}$} & $\begin{array}{l}\text { minister Kazimierz } \\
\text { Sosnkowski }\end{array}$ & 2 & - & \multirow{3}{*}{11} \\
\hline & $\begin{array}{c}\text { minister Władysław } \\
\text { Sikorski }\end{array}$ & - & 5 & \\
\hline & $\begin{array}{c}\text { przedstawiciel } \\
\text { ppłk Tadeusz Petrażycki }\end{array}$ & 2 & 2 & \\
\hline \multirow{3}{*}{$\begin{array}{l}\text { Ministerstwo } \\
\text { Sprawiedliwości }\end{array}$} & $\begin{array}{l}\text { minister Włodzimierz } \\
\text { Wyganowski }\end{array}$ & - & 2 & \multirow{3}{*}{5} \\
\hline & minister Antoni Żychliński & - & 2 & \\
\hline & $\begin{array}{c}\text { podsekretarz stanu Julian } \\
\text { Siennicki }\end{array}$ & - & 1 & \\
\hline \multirow{3}{*}{$\begin{array}{l}\text { Ministerstwo Wyznań } \\
\text { Religijnych i Oświecenia } \\
\text { Publicznego }\end{array}$} & $\begin{array}{l}\text { minister Bolesław } \\
\text { Miklaszewski }\end{array}$ & - & 1 & \multirow{3}{*}{3} \\
\hline & minister Stanisław Grabski & - & 1 & \\
\hline & $\begin{array}{l}\text { wiceminister Tadeusz } \\
\text { Łopuszański }\end{array}$ & - & 1 & \\
\hline \multirow{2}{*}{$\begin{array}{l}\text { Ministerstwo Przemysłu } \\
\text { i Handlu }\end{array}$} & minister Józef Kiedroń & 3 & 3 & \multirow{2}{*}{7} \\
\hline & minister Czesław Klarner & - & 1 & \\
\hline \multirow{2}{*}{$\begin{array}{l}\text { Ministerstwo Rolnictwa } \\
\text { i Dóbr Państwowych }\end{array}$} & minister Stanisław Janicki & - & 4 & \multirow[b]{2}{*}{6} \\
\hline & $\begin{array}{l}\text { wiceminister Józef } \\
\text { Raczyński }\end{array}$ & 1 & 1 & \\
\hline $\begin{array}{l}\text { Ministerstwo Reform } \\
\text { Rolnych }\end{array}$ & kierownik Józef Radwan & - & 2 & 2 \\
\hline Ministerstwo Kolei & minister Kazimierz Tyszka & - & 3 & 3 \\
\hline $\begin{array}{l}\text { Ministerstwo Robót } \\
\text { Publicznych }\end{array}$ & $\begin{array}{c}\text { kierownik Mieczysław } \\
\text { Rybczyński }\end{array}$ & 2 & 3 & 5 \\
\hline \multirow{3}{*}{$\begin{array}{l}\text { Ministerstwo Pracy } \\
\text { i Opieki Społecznej }\end{array}$} & kierownik Gustaw Simon & 3 & 1 & \multirow{3}{*}{8} \\
\hline & minister Franciszek Sokal & - & 2 & \\
\hline & $\begin{array}{c}\text { podsekretarz stanu Gustaw } \\
\text { Simon }\end{array}$ & - & 2 & \\
\hline
\end{tabular}

Źródło: opracowanie własne na podstawie: Sejm II RP, I kad., Spr. Sten. 89. pos. z 20 XII 1923 - Spr. Sten. 254. pos. z 13 XI 1925. 
Dane zawarte w tabeli 2 dowodzą, że - zgodnie z powtarzającym się trendem w zakresie realizowanych reform ekonomiczno-walutowych - najwięcej przemówień w ramach czytań rządowych projektów ustaw, w liczbie 35, wygłosili przedstawiciele Ministerstwa Skarbu. Do tego doliczyć należy 19 wystąpień premiera Władysława Grabskiego i jednocześnie przecież ministra skarbu. Na drugim miejscu, z łącznie 11 wystąpieniami, znaleźli się dwaj kolejni ministrowie spraw wojskowych - Kazimierz Sosnkowski i Władysław Sikorski - oraz przedstawiciel tego resortu ppłk Tadeusz Petrażycki. Najmniejszą aktywność w zakresie udziału w czytaniach rządowych projektów ustaw wykazały resorty: kolei, reform rolnych i spraw zagranicznych. Warto również odnotować, co daje się zauważyć w powyższej tabeli, że w wielu przypadkach referowaniem stanowiska danego ministerstwa na forum sejmu nie zajmował się bezpośrednio minister. Misję tę często powierzano zaznajomionym w konkretnych sprawach wiceministrom, podsekretarzom stanu i dyrektorom departamentów.

Wystąpienia Prezesa Rady Ministrów i ministra skarbu Władysława Grabskiego co do zasady dotyczyły procedowanych w sejmie ustaw o znaczeniu strategicznym. W tym zakresie mieściło się zabranie przez niego głosu 4 i 5 stycznia 1924 roku w toku debaty nad wspomnianymi już tzw. pierwszymi pełnomocnictwami ${ }^{8}$. Po przyjęciu tego rodzaju rozwiązania na okres półroczny po tym czasie premier zwrócił się do Sejmu z podobnym wnioskiem na kolejne sześć miesięcy. W związku z tym Grabski przemawiał na mównicy sejmowej ponownie 15 i 16 lipca 1924 roku w ramach dyskusji o drugich pełnomocnictwach ${ }^{9}$.

Innym przykładem debat o kluczowym znaczeniu z udziałem szefa rządu były plenarne rozprawy nad ustawami skarbowymi. Warto podkreślić, że tego rodzaju wypowiedzi miały doniosłe znaczenie nie tylko ze względu na możliwość zaprezentowania rządowego stanowiska w kwestii wysokości wydatków i dochodów środków publicznych (związanych z administracją, firmami państwowymi, monopolami i funduszami). Omawiany dokument regulował pod względem finansowym różne dziedziny działań władz państwowych, które bezpośrednio oddziaływały na obywateli. Dzięki temu wyróżniające się długością rzeczone wystąpienia przybierały postać niejako kolejnych exposé, w ramach których premier prezentował posłom kierunki prowadzonej przez niego polityki. Rezultatem tego stawały się równoległe wnioski poselskie o wyrażenie wotum nieufności dla rządu ${ }^{10}$. W celu usystematyzowania niniejszych treści warto wyliczyć, że premier i minister skarbu Władysław Grabski zabierał głos:

${ }^{8}$ Sejm II RP, I kad., Sprawozdanie Stenograficzne [dalej: Spr. Sten.] 91. posiedzenia [dalej: pos.] z 4 I 1924, ł. 12-25; Sejm II RP, Spr. Sten. 92. pos. z 5 I 1924, 1. 8; Ustawa z dnia 11 stycznia 1924 r. o naprawie Skarbu Państwa i reformie walutowej (Dz.U. z 1924 r., nr 4, poz. 28).

9 Sejm II RP, Spr. Sten. 150. pos. z 15 VII 1924, 1. 49-51; Sejm II RP, Spr. Sten. 151. pos. z 16 VII 1924, 1. 39 i n.; Ustawa z dnia 31 lipca 1924 r. o naprawie Skarbu Państwa i poprawie gospodarstwa społecznego (Dz.U. z 1924 r., nr 71, poz. 687). Zob. P. Go fro n, op. cit.

${ }^{10} \mathrm{Na}$ przykład 11 listopada 1924 r. zgłoszone zostały trzy - w rezultacie odrzucone - wnioski posłów Pawła Wasyńczuka z Klubu Ukraińskiego, Wasila Roguli z Klubu Białoruskiego i Józefa Skrzypy z Klubu Ukraińskiego o udzielenie drugiemu gabinetowi Władysława Grabskiego wotum nieufności i o odrzucenie preliminarza budżetowego na rok 1925 (Sejm II RP, I kad., Spr. Sten. 161. pos. z 11 XI 1924, 1. 17 i n.). 
- trzykrotnie w ramach debaty nad ustawą skarbową na rok 1924 (10 i 14 czerwca oraz 8 lipca 1924 roku) $)^{11}$;

- czterokrotnie w dyskusji nad ustawą skarbową na 1925 rok (22 i 29 października oraz 7 listopada 1924 roku, a także 18 kwietnia 1925 roku) ${ }^{12}$;

- trzykrotnie w rozprawie plenarnej nad założeniami ustawy skarbowej na rok $1926(6,20 \text { i } 23 \text { października } 1925 \text { roku })^{13}$.

W pozostałych przypadkach wystąpienia premiera i ministra skarbu Grabskiego dotyczyły innych rządowych projektów ustaw, niemniej jednak dalej powiązanych tematycznie z finansami publicznymi. Były to bowiem przemówienia w ramach debat nad propozycją uregulowań prawnych w zakresie kar za zwłokę w uiszczaniu należności podatkowych ${ }^{14}$, ratyfikacji układu konsolidacji długów amerykańskich ${ }^{15}$, monopolu zapałczanego ${ }^{16}$ oraz środków złagodzenia przesilenia finansowego ${ }^{17}$. Prezes Rady Ministrów zabrał również głos w sejmowym procedowaniu projektu reformy rolnej ${ }^{18}$.

Poszczególni ministrowie i przedstawiciele resortów wypowiadali się na forum sejmu głównie przy okazji czytań projektów ustaw przygotowanych za ich urzędowania bądź opracowanych wcześniej w ministerstwach, które reprezentowali. Na przykład 2 kwietnia 1924 roku minister rolnictwa i dóbr państwowych Stanisław Janicki przekonywał posłów w debacie nad ustawą o podatku od zwierząt domowych, że środki pozyskane z tego tytułu będą przeznaczone na zwalczanie zagrożenia rozprzestrzenienia się chorób weterynaryjnych ${ }^{19}$. W toku procedowania propozycji poprzedniego rządu dotyczących uregulowań prawnych w zakresie praw i obowiązków szeregowych Wojska Polskiego przedstawiciel Ministerstwa Spraw Wojskowych ppłk Tadeusz Petrażycki w swoim wystąpieniu z 27 maja 1924 roku odniósł się głównie do poprawek wniesionych przez posłów. W tym kontekście poinformował, że jest zmuszony odrzucić postulat skrócenia czasu dla uzyskania stopnia podoficera, gdyż „,ceni się to, co z trudem się zdobywa" 20 . Szczegółową listę rządowych projektów ustaw, w których procedowaniu w izbie poselskiej udział wzięli przedstawiciele drugiego gabinetu Władysława Grabskiego, zawiera tabela 3 .

${ }^{11}$ Sejm II RP, I kad., Spr. Sten. 126. pos. z 10 VI 1924, ł. 16-45; Sejm II RP, Spr. Sten. 130. pos. z 14 VI 1924, 1. 9-26; Sejm II RP, Spr. Sten. 145. pos. z 8 VII 1924, 1. 38 i n.

${ }^{12}$ Sejm II RP, Spr. Sten. 155. pos. z 22 X 1924, 1. 6-37; Sejm II RP, Spr. Sten. 157. pos. z 29 i 30 X 1924, 1.3 i n.; Sejm II RP, Spr. Sten. 160. pos. z 7 XI 1924, 1. 2-40; Sejm II RP, Spr. Sten. 198. pos. z 28 IV 1925, 1. 54-76.

${ }_{13}$ Sejm II RP, Spr. Sten. 241. pos. z 6 X 1925, 1. 9-17; Sejm II RP, Spr. Sten. 242. pos. z 10 X 1925, 1. 53 i n.; Sejm II RP, Spr. Sten. 245. pos. z 23 X 1925, ł. 4-22.

${ }^{14}$ Sejm II RP, Spr. Sten. 152. pos. z 17 VII 1924, 1. 30 i n.

${ }^{15}$ Sejm II RP, Spr. Sten. 175. pos. z 23 I 1925, 1.13 i n.

${ }_{16}$ Sejm II RP, Spr. Sten. 230. pos. z 8 VII 1925, 1. 25-27.

${ }^{17}$ Sejm II RP, Spr. Sten. 252. pos. z 11 XI 1925, 1. 59-65.

${ }^{18}$ Sejm II RP, Spr. Sten. 231. pos. z 10 VII 1925, 1. 5-9.

19 Sejm II RP, Spr. Sten. 106. pos. z 2 IV 1924, ł. 16-18.

${ }^{20}$ Sejm II RP, Spr. Sten. 122. pos. z 27 V 1924, ł. 38 i n. 
Tabela 3. Lista rządowych projektów ustaw procedowanych w Sejmie II Rzeczypospolitej I kadencji z udziałem członków drugiego gabinetu Władysława Grabskiego

\begin{tabular}{|c|c|c|}
\hline $\begin{array}{l}\text { Autorstwo rzą- } \\
\text { dowego projektu } \\
\text { ustawy }\end{array}$ & Lp. & Nazwa rządowego projektu ustawy \\
\hline \multirow{8}{*}{$\begin{array}{l}\text { Projekty ustaw } \\
\text { wniesione przez } \\
\text { poprzednie rządy }\end{array}$} & 1 & Ustawa w sprawie przepisów o państwowym podatku majątkowym \\
\hline & 2 & Ustawa o powszechnym obowiązku służby wojskowej \\
\hline & 3 & Ustawa o ochronie najemców \\
\hline & 4 & Ustawa o zabezpieczeniu na wypadek bezrobocia \\
\hline & 5 & Ustawa o pomocy państwowej na odbudowę \\
\hline & 6 & Ustawa o poczcie, telegrafie i telefonie \\
\hline & 7 & Ustawa o obowiązkach i prawach szeregowych \\
\hline & 8 & Ustawa o rozpłodnikach zwierząt gospodarskich \\
\hline \multirow{26}{*}{$\begin{array}{c}\text { Projekty ustaw wnie- } \\
\text { sione przez drugi } \\
\text { gabinet Władysława } \\
\text { Grabskiego }\end{array}$} & 9 & Ustawa o podatku od zwierząt domowych \\
\hline & 10 & Ustawa o opodatkowaniu piwa \\
\hline & 11 & $\begin{array}{l}\text { Ustawa o sposobie zapłacenia podatku majątkowego przez sprze- } \\
\text { daż majątków }\end{array}$ \\
\hline & 12 & Ustawa o zakwaterowaniu wojska \\
\hline & 13 & Ustawa o komisjach rozjemczych w rolnictwie \\
\hline & 14 & Ustawa celna \\
\hline & 15 & Ustawa o zmianie Statutu Banku Polskiego \\
\hline & 16 & Nowela do ustawy o opodatkowaniu spadków i darowizn \\
\hline & 17 & Ustawa o monopolu spirytusowym \\
\hline & 18 & Ustawa o obrocie cukrem \\
\hline & 19 & Ustawa o dodatkowych kredytach na rok 1924 \\
\hline & 20 & Ustawa o opłatach weterynaryjnych \\
\hline & 21 & Ustawa o mierniczych przysięgłych \\
\hline & 22 & Ustawa o wypuszczeniu pożyczki w dolarach \\
\hline & 23 & $\begin{array}{l}\text { Ustawa o zgromadzeniach zwoływanych przez członków Izb } \\
\text { Ustawodawczych }\end{array}$ \\
\hline & 24 & Ustawa o budowie domów mieszkalnych w miastach \\
\hline & 25 & $\begin{array}{l}\text { Ustawa o opłatach za nadzór nad zdrowotnością zwierząt domo- } \\
\text { wych, oddanych do przewozu i na ubój }\end{array}$ \\
\hline & 26 & Ustawa o poborze rekruta w 1925 roku \\
\hline & 27 & Ustawa o wyłączności portów polskich dla wychodźstwa \\
\hline & 28 & Ustawa o budowie kolei Kalety - Herby - Wieluń - Podzamcze \\
\hline & 29 & Ustawa o parcelacji i osadnictwie \\
\hline & 30 & Ustawa o organizacji więziennictwa \\
\hline & 31 & Preliminarz budżetowy na rok 1924 \\
\hline & 32 & Ustawa o preliminarzu budżetowym na rok 1925 \\
\hline & 33 & Ustawa o prowizorium budżetowym na marzec i kwiecień 1925 roku \\
\hline & 34 & Preliminarz budżetowy na rok 1926 \\
\hline
\end{tabular}

Źródło: opracowanie własne na podstawie: Sejm II RP, I kad., Spr. Sten. 89. pos. z 20 XII 1923 - Spr. Sten. 254. pos. z 13 XI 1925. 
W świetle przedstawionych danych okazuje się, że wniesione do sejmu przez poprzednie gabinety projekty ustaw zostały w pewnym zakresie uznane za zgodne z polityką drugiego rządu Grabskiego, gdyż wchodzący w jego skład ministrowie podjęli nad nimi dyskusję w ramach debat plenarnych na forum sejmu. Podsumowując dwa powyższe zestawienia, warto zauważyć, że spośród 300 projektów ustaw złożonych w Sejmie II Rzeczypospolitej I kadencji przez premiera Grabskiego i jego ministrów komentowanych z mównicy sejmowej było łącznie 36, co stanowi $12 \%$. Większa aktywność przedstawicieli rządu w ramach procedowania ustaw przez nich wniesionych odbywała się, zgodnie z utartym zwyczajem, na posiedzeniach komisji sejmowych ${ }^{21}$.

\section{III}

Premier Władysław Grabski i członkowie jego gabinetu - ministrowie, wiceministrowie i reprezentanci poszczególnych resortów - brali również udział w czytaniach poselskich i klubowych projektów ustaw. Spośród wszystkich 151 wystąpień przedstawicieli tego rządu na forum Sejmu II Rzeczypospolitej I kadencji, w tym 122 dotyczących procesów legislacyjnych, przedmiotem 12 wypowiedzi było przedstawienie stanowiska Rady Ministrów i poszczególnych ministerstw do łącznie ośmiu propozycji uregulowań prawnych wniesionych przez posłów i kluby sejmowe. Szczegółowe zestawienie rzeczonych wystąpień zawiera tabela 4.

Tabela 4. Wystąpienia członków drugiego rządu Władysława Grabskiego w ramach czytań poselskich i klubowych projektów ustaw

\begin{tabular}{|l|c|c|}
\hline \multicolumn{1}{|c|}{ Resort } & Prelegent & $\begin{array}{c}\text { Liczba } \\
\text { wystąpień }\end{array}$ \\
\hline Ministerstwo Skarbu & wiceminister Bolesław Markowski & 7 \\
\hline & wiceminister Czesław Klarner & 2 \\
\hline & dyrektor departamentu Marian Głowacki & 1 \\
\hline $\begin{array}{l}\text { Ministerstwo Rolnictwa i Dóbr } \\
\text { Państwowych }\end{array}$ & wiceminister Józef Karśnicki & 1 \\
\hline \multicolumn{1}{|c|}{ RAZEM } & wiceminister Józef Raczyński & 1 \\
\hline
\end{tabular}

Źródło: opracowanie własne na podstawie: Sejm II RP, I kad., Spr. Sten. 138. pos. z 27 VI 1924, 1. 69 i n.; Sejm II RP, Spr. Sten. 145. pos. z 8 VII 1924, ł. 50-52; Sejm II RP, Spr. Sten. 169. pos. z 12 XII 1924, 1. 58 i n.; Sejm II RP, Spr. Sten. 192. pos. z 2 IV 1925, ł. 84 i n.; Sejm II RP, Spr. Sten. 199. pos. z 29 IV 1925, ł. 15-19; Sejm II RP, Spr. Sten. 210. pos. z 26 V 1925, ł. 11; Sejm II RP, Spr. Sten. 217. pos. z 18 VI 1925, ł. 20-23, 62 i n., 67 i n.; Sejm II RP, Spr. Sten. 219. pos. z 22 VI 1925, ł. 11 i n.; Sejm II RP, Spr. Sten. 236. pos. z 16 VII 1925, ł. 25, 37 i n.

${ }^{21}$ Tezę taką postawił m.in. Andrzej Ajnenkiel, badacz dziejów parlamentaryzmu polskiego. Jego zdaniem ciała te stanowiły forum spotkań członków rządu z parlamentem. Odbywające się tam posiedzenia miały częstokroć charakter roboczy, a w wielu przypadkach również poufny. A. Ajnenkiel, Historia sejmu polskiego, t. 2, cz. 2, Warszawa 1989, s. 108). 
Na podstawie danych zamieszczonych w powyższym zestawieniu wyliczyć można następujące uwagi i spostrzeżenia. Po pierwsze, w czytaniach poselskich i klubowych projektów ustaw osobiście nie brał udziału premier Grabski. Po drugie, w ramach tego typu dyskusji przemawiali przedstawiciele tylko dwóch resortów, spośród których najaktywniejsze okazało się Ministerstwo Skarbu. Nie powinno to zaskakiwać, jeśli weźmie się pod uwagę silne akcentowanie przez ten gabinet reform finansów publicznych i uznanie ich za priorytet prowadzonej przezeń polityki.

Warto wyjaśnić, że stosunkowo niewielki odsetek wystąpień członków rządu w przedmiocie czytania projektów ustaw wniesionych przez posłów ${ }^{22}$ był wynikiem znikomej aktywności członków izby poselskiej w ramach przyznanego im przez Konstytucję marcową prawa inicjatywy ustawodawczej. Wśród propozycji uregulowań prawnych wniesionych do sejmu wyraźnie bowiem dominują te, których autorami byli premier i jego ministrowie. Poselskie i klubowe projekty ustaw stanowiły niewielki ułamek tego typu dokumentów ${ }^{23}$.

Spośród łącznie ośmiu procesów legislacyjnych zainicjowanych przez członków izby niższej parlamentu, w których udział wzięli członkowie drugiego rządu Władysława Grabskiego, cztery regulowały sprawy skarbowo-budżetowe, trzy kolejne miały charakter socjalny, jedna natomiast dotyczyła nowelizacji ustawy o policji państwowej. Ze względu na to, że tego rodzaju wystąpienia ministerialne stanowiły stosunkowo niewielki odsetek wszystkich sejmowych mów (co mogło sprawiać wrażenie, że poruszane sprawy były w ocenie rządu istotne), warto przyjrzeć się pokrótce kilku najistotniejszym debatom.

Do pierwszej z wyżej wymienionych kategorii zaliczyć należy rozprawę nad ustawą w sprawie opłat za paszporty na wyjazd za granicę. Proces jej procedowania na forum sejmu zainicjowany został złożeniem wniosków przez posłów Polskiego Stronnictwa Ludowego „Piast” z 13 marca 1924 roku i deputowanych Koła Żydowskiego z 2 kwietnia 1924 roku. Pierwszy z nich dotyczył wezwania rządu do zniesienia opłat od paszportów dla wszystkich robotników, którzy emigrują w celu poszukiwania pracy ${ }^{24}$. Autorzy drugiego apelowali natomiast do gabinetu o ustalenie takich opłat paszportowych, które odpowiadałyby stawkom w innych krajach europejskich $^{25}$. Obydwa dokumenty zostały odesłane do Komisji Skarbowej, która następnie ,większością głosów uznała uregulowanie opłat paszportowych drogą ustawy za konieczne, zarówno w celu stworzenia podstawy prawnej dla pobierania tego rodzaju opłat w ogóle, jak i w celu położenia tamy dowolności władz wykonawczych przy udzielaniu pozwoleń na wyjazd za granicę"26. Wystąpienie sprawozdawcy posła Władysława Byrki rozpoczęło 8 lipca 1924 roku debatę nad rekomendowaną

${ }^{22}$ Liczba wystąpień członków gabinetu w ramach czytania poselskich i klubowych projektów ustaw stanowiła około $8 \%$ wszystkich przemówień rządowych.

23 A. Ajnenkie1, Historia sejmu..., s. 107 i n.

${ }^{24}$ Sejm II RP, I kad., Druk nr 1075, Wniosek posłów Brunona Stanisława Gruszki, Władysława Kiernika i kolegów z Klubu Polskiego Stronnictwa Ludowego „Piast” w sprawie opłat paszportowych.

${ }^{25}$ Sejm II RP, Druk nr 1134, Wniosek posłów Henryka Rosmarina, Abrahama Inslera i towarzyszy z Koła Żydowskiego w sprawie opłat paszportowych.

26 Sejm II RP, Druk nr 1292, Sprawozdanie Komisji Skarbowej o wnioskach: a) posłów Brunona Stanisława Gruszki, Władysława Kiernika i kolegów z Klubu Polskiego Stronnictwa Ludowego „Piast”, 
do uchwalenia przez posłów ustawą. Zakładała ona - jak referował prelegent że wysokość opłat paszportowych będzie regulował minister spraw wewnętrznych $\mathrm{w}$ porozumieniu $\mathrm{z}$ ministrem skarbu ${ }^{27}$.

Po zgłoszeniu przez posłów poprawek stanowisko rządu wobec tych propozycji przedstawił wiceminister skarbu Czesław Klarner. W swoim wystąpieniu przekonywał on, że wprowadzona w lutym 1924 roku i przywoływana częstokroć w toku debaty opłata paszportowa w wysokości 500 zł stanowiła bezpośrednie narzędzie sanacji Skarbu Państwa i - zgodnie z zamiarami decydentów - miała dotyczyć przede wszystkim tych, „którzy wyjeżdżają dla tego lub innego luksusu” ${ }^{28}$. Wobec tego, że proponowana ustawa dawała możliwość ustalenia stawek przez rząd, wiceminister Klarner ostatecznie poparł ten projekt, tym bardziej że zgadzał się z pomysłem obniżenia należności w wyliczonych wyjątkach ${ }^{29}$. Finalnie, po głosowaniu nad wniesionymi poprawkami, ustawa została przez posłów przyjęta w trzecim czytaniu ${ }^{30}$, a następnie opublikowana w Dzienniku Ustaw ${ }^{31}$.

Kolejny proces ustawodawczy dotyczący problematyki finansowo-budżetowej, zainicjowany przez klub Związku Ludowo-Narodowego wnioskiem posłów tego ugrupowania z 12 grudnia 1924 roku, dotyczył zmiany rozporządzenia prezydenta o przerachowaniu pożyczek państwowych. Wnioskodawcy domagali się znowelizowania wysokości pożyczki konwersyjnej dla posiadaczy obligacji pożyczki długoterminowej i krótkoterminowej z 1920 roku oraz przyznania posiadaczom pierwszego rodzaju kredytu $10 \%$ nadwyżki ${ }^{32}$. W rezultacie w Komisji Skarbowej opracowano uzgodniony $\mathrm{z}$ rządem stosowny projekt ustawy ${ }^{33}$, nad którym procedowanie rozpoczęto 29 kwietnia 1925 roku wystąpieniem głównego referenta posła Karola Rzepeckiego ${ }^{34}$.

W tym samym dniu w drugim czytaniu wiceminister skarbu Czesław Klarner wyraził poparcie dla projektu omawianego aktu prawnego. Analizowane wystąpienie

b) posłów Henryka Rosmarina, Abrahama Inslera i towarzyszy z Koła Żydowskiego w sprawie opłat paszportowych (Sejm II RP, I kad., Druki nr 1075 i 1134).

${ }^{27}$ Sejm II RP, I kad., Spr. Sten. 145. pos. z 8 VII 1924, ł. 48 i n. Dodatkowo rzeczony projekt przewidywał ujednolicenie i odgórne ustalenie stawek w kilku konkretnych przypadkach, jak chociażby za wydanie paszportu dla osób udających się za granicę w celach handlowych, edukacyjnych, społecznych, dyplomatycznych i z zamiarem podjęcia leczenia.

${ }^{28}$ Sejm II RP, I kad., Spr. Sten. 145. pos. z 8 VII 1924, ł. 50.

${ }^{29}$ Ibidem, 1. 50-52.

${ }^{30}$ Sejm II RP, I kad., Spr. Sten. 147. pos. z 10 VII 1924, ł. 26.

${ }^{31}$ Ustawa z dnia 17 lipca 1924 r. w sprawie opłat za paszporty na wyjazd za granicę (Dz.U. z 1994 r., nr 69, poz. 672).

${ }^{32}$ Sejm II RP, Druk nr 1622, Wniosek posłów Karola Rzepeckiego, Juliana Łabędy, Franciszka Urbańskiego, Ignacego Redera, Jana Faustyniaka, Wojciecha Sikory, ks. Stefana Bratkowskiego i kolegów w sprawie zmiany rozporządzenia Prezydenta Rzeczypospolitej Polskiej z dnia 17 marca 1924 r. o przerachowaniu pożyczek państwowych

${ }^{33}$ Sejm II RP, Druk nr 1817, Sprawozdanie Komisji Skarbowej o wniosku posła Karola Rzepeckiego i kolegów z dnia 12 grudnia 1924 r., dotyczącego zmiany rozporządzenia Prezydenta Rzeczypospolitej Polskiej z dnia 17 marca 1924 r. o przerachowaniu pożyczek państwowych oraz o rządowym projekcie ustawy, dotyczącej konwersji rzeczowych pożyczek, jako też rozporządzenia z dnia 28 grudnia 1924 r. (Dz.U. z 1924 r., nr 114, poz. 1021) w przedmiocie przedłużenia terminu tejże konwersji (Sejm II RP, I kad., Druki nr 1622 i 1697).

${ }^{34}$ Sejm II RP, I kad., Spr. Sten. 199. pos. z 29 IV 1924, ł. 9-13. 
uznać można za bardzo merytoryczne, prelegent bowiem niejednokrotnie opierał się na konkretnych danych liczbowych, dokładnie określając chociażby bieżące i prognozowane sumy skonwertowanych i zwaloryzowanych papierów wartościowych ${ }^{35}$. W trakcie odbywającego się niespełna miesiąc później trzeciego czytania omawianego projektu ustawy przemawiał kolejny reprezentant resortu skarbu - wiceminister Józef Karśnicki. Tym razem przedstawiciel rządu ograniczył swoje wystąpienie do - nieuwzględnionej w rezultacie przez posłów - rekomendacji odrzucenia dwóch wniesionych poprawek ${ }^{36}$.

Jeszcze innym projektem ustawy dotyczącej kwestii budżetowej i procedowanej przy czynnym udziale członka drugiego rządu Grabskiego była proponowana przez posłów nowelizacja regulacji w zakresie podatku przemysłowego. Podwalinami jej skonstruowania było pięć wniosków, w tym cztery poselskie, złożone w sejmie odpowiednio przez: Polskie Stronnictwo Ludowe „Wyzwolenie” i „Jedność Ludowa” (dwa projekty) $^{37}$, Związek Ludowo-Narodowy ${ }^{38}$ i Związek Chłopski ${ }^{39}$. W pakiecie powyższych pism znalazł się również wniosek rządowy przygotowany przez Ministerstwo $\mathrm{Skarbu}^{40}$. Po zakończeniu rozpatrywania tychże dokumentów Komisja Skarbowa w dniu 18 czerwca 1925 roku przedstawiła na forum sejmu sprawozdanie z uzgodnionym projektem ustawy o państwowym podatku przemysłowym ${ }^{41}$.

35 Ibidem, 1. 15-19.

36 Sejm II RP, I kad., Spr. Sten. 210. pos. z 26 V 1925, ł. 11. Wiceminister Karśnicki rekomendował posłom przywrócenie brzmienia pierwotnego art. 5 omawianego projektu ustawy i nieprzyjęcie poprawki zgłoszonej do art. 9. Ustawa z dnia 20 lipca 1925 r. o uzupełnieniu rozporządzenia Prezydenta Rzeczypospolitej z dnia 17 marca 1924 r. o przerachowaniu zobowiązań Skarbu Państwa z tytułu pożyczek państwowych oraz konwersji rzeczonych pożyczek oraz rozporządzenia Prezydenta Rzeczypospolitej z dnia 28 grudnia 1924 r. (Dz.U. z 1925 r., nr 90, poz. 629).

37 Sejm II RP, I kad., Druk nr 1509, Wniosek posła Franciszka Kapelińskiego i towarzyszy z Klubu Związku Polskich Stronnictw Ludowych „Wyzwolenie” i „Jedność Ludowa” w sprawie zmiany opodatkowania przedmiotów zbytku; Sejm II RP, Druk nr 1568, Wniosek posła Józefa Sanojcy i kolegów z Klubu Związku Polskich Stronnictw Ludowych „Wyzwolenie” i „Jedność Ludowa” w sprawie wymiaru podatku przemysłowego (obrotowego).

38 Sejm II RP, Druk nr 1678, Wniosek posłów Związku Ludowo-Narodowego w sprawie nowelizacji ustawy z dnia 14 maja 1923 r. w przedmiocie państwowego podatku przemysłowego.

39 Sejm II RP, Druk nr 1715, Wniosek posła Michała Łaskudy i towarzyszy z Poselskiego Klubu Związku Chłopskiego w sprawie noweli do ustawy z dnia 14 maja 1923 r. (Dz.U. z 1923 r., nr 58, poz. 412) o podatku przemysłowym.

${ }^{40}$ Sejm II RP, Druk nr 1731, Projekt ustawy o zmianie niektórych postanowień: 1) ustawy z dnia 14 maja 1923 r. (Dz.U. z 1923 r., nr 58, poz. 412) w przedmiocie państwowego podatku przemysłowego, 2) ustawy z dnia 9 lipca 1924 r. (Dz.U. z 1924 r., nr 69, poz. 670) oraz o uchyleniu mocy obowiązującej ustawy z dnia 16 lipca 1920 r. (Dz.U. z 1920 r., nr 79, poz. 528) o połacie stemplowej do sprzedaży przedmiotów zbytku.

${ }^{41}$ Sejm II RP, Druk nr 1987, Sprawozdanie Komisji Skarbowej 1) o rządowych projektach ustaw o zmianie niektórych postanowień: a) ustawy z dnia 14 maja 1923 r. (Dz.U. z 1923 r., nr 58, poz. 412) w przedmiocie państwowego podatku przemysłowego; b) ustawy z dnia 9 lipca 1924 r. (Dz.U. z 1924 r., nr 69, poz. 670) oraz o uchyleniu mocy obowiązującej ustawy z dnia 16 lipca 1920 r. (Dz.U. z 1920 r., nr 79 , poz. 528) o połacie stemplowej do sprzedaży przedmiotów zbytku (Sejm II RP, I kad., Druk nr 1731); 2) o wnioskach: a) posła Franciszka Kapelińskiego i towarzyszy z Klubu Związku Polskich Stronnictw Ludowych „Wyzwolenie” i „Jedność Ludowa” w sprawie zmiany opodatkowania przedmiotów zbytku (Sejm II RP, I kad., Druk nr 1509); b) posła Józefa Sanojcy i kolegów z Klubu Związku Polskich 
W trakcie drugiego czytania stosunek gabinetu Grabskiego wobec niniejszej propozycji przedstawił, trzykrotnie zabrawszy głos, wiceminister skarbu Bolesław Markowski. Zwracając się do posłów, mówił on, że rząd dostrzegł potrzebę zmniejszenia stawki podatku obrotowego i w celu zrealizowania tego zamysłu zaproponował osiem rodzajów ulg w tym zakresie, mimo że wprowadzenie ich w życie miało poskutkować zmniejszonymi o 48 milionów zł wpływami z tego tytułu do budżetu państwa. Jednocześnie rekomendował członkom izby poselskiej przyjęcie pierwotnego, popartego przez rząd projektu ustawy bez naniesionych poprawek Komisji Skarbowej, które za sprawą dalszego rozszerzenia ulg przyniosłyby niedopuszczalny spadek dochodu o kolejne 42 miliony $\mathrm{z}^{42}$.

W trzecim czytaniu ustawy, które odbyło się 22 czerwca 1925 roku, głos ze strony rządowej ponownie zabrał wiceminister Markowski. W wystąpieniu poprzedzającym głosowanie nad całością ustawy (ostatecznie przez posłów przyjętej ${ }^{43}$ ) zastrzegł on, że jeśli sejm uchwali niepopierane przez niego daleko idące dodatkowe ulgi w podatku przemysłowym, gabinet Grabskiego nie będzie mógł wziąć odpowiedzialności za utrzymanie równowagi budżetowej ${ }^{44}$.

Jak zostało wspomniane, kilka spośród poselskich i klubowych propozycji uregulowań prawnych, w których procedowaniu na forum sejmu aktywnie uczestniczyli przedstawiciele drugiego rządu Władysława Grabskiego, miało charakter socjalny. Jeden z nich - projekt ustawy w przedmiocie ochrony drobnych dzierżawców rolnych wraz z nowelizacją adekwatnych ustaw -został zaproponowany sejmowi przez Komisję Rolną 20 czerwca 1924 roku $^{45}$. Stanowił on zasadniczo konsekwencję dwóch wniosków, których celem było przedłużenie obowiązywania przepisów prawnych gwarantujących drobnym dzierżawcom rolnym przywileje ochronne, złożonych odpowiednio przez posła Tadeusza Seiba z Polskiego Stronnictwa Ludowego „Wyzwolenie” i „Jedność Ludowa”46 oraz posłów z klubu Polskiego Stronnictwa Ludowego „Piast" ${ }^{47}$.

Stronnictw Ludowych „Wyzwolenie” i „Jedność Ludowa” w sprawie wymiaru podatku przemysłowego (obrotowego) (Sejm II RP, I kad., Druk nr 1568); c) posłów Związku Ludowo-Narodowego w sprawie nowelizacji ustawy z dnia 14 maja $1923 \mathrm{r}$. w przedmiocie państwowego podatku przemysłowego (Sejm II RP, I kad., Druk Nr 1678); d) posła Michała Łaskudy i towarzyszy z Poselskiego Klubu Związku Chłopskiego w sprawie noweli do ustawy z dnia 14 maja 1923 r. (Dz.U. z 1923 r., nr 58, poz. 412) o podatku przemysłowym (Sejm II RP, I kad., Druk nr 1715).

${ }^{42}$ Sejm II RP, I kad., Spr. Sten. 217. pos. z 18 VI 1925, ł. 20-23, 62 i n., 67 i n.

${ }^{43}$ Ustawa z dnia 15 lipca 1925 r. o państwowym podatku przemysłowym (Dz.U. z 1925 r., nr 79, poz. 550).

${ }^{44}$ Sejm II RP, I kad., Spr. Sten. 219. pos. z 22 VI 1925, ł. 11 i n.

${ }^{45}$ Sejm II RP, Druk nr 1293, Sprawozdanie Komisji Rolnej w przedmiocie wniosków posłów Tadeusza Seiba i towarzyszy z Polskiego Stronnictwa Ludowego „Wyzwolenie” i „Jedność Ludowa” oraz posłów Antoniego Pasickiego i towarzyszy z Klubu Polskiego Stronnictwa Ludowego „Piast” w sprawie przedłużenia mocy ustawy z dnia 2 lipca 1920 r. o ochronie drobnych dzierżawców rolnych (Sejm II RP, I kad., Druki nr 1018 i 1020).

${ }^{46}$ Sejm II RP, Druk nr 1018, Wniosek posła Tadeusza Seiba i towarzyszy z Klubu Polskiego Stronnictwa Ludowego „Wyzwolenie” i „Jedność Ludowa” w sprawie przedłużenia mocy obowiązującej ustawy o ochronie drobnych dzierżawców rolnych z dnia 2 lipca 1920 r. (Dz.U. z 1920 r., nr 56, poz. 346).

${ }^{47}$ Sejm II RP, Druk nr 1020, Wniosek posłów Klubu Polskiego Stronnictwa Ludowego „Piast” w przedmiocie ochrony drobnych dzierżawców rolnych, a w szczególności zmiany niektórych przepisów 
Biorący czynny udział w debacie plenarnej wiceminister rolnictwa i dóbr państwowych Józef Raczyński zwrócił uwagę na poprawkę wniesioną przez posła Michała Janeczka, zgodnie z którą wykonanie omawianej ustawy zostało powierzone również Ministerstwu Rolnictwa i Dóbr Państwowych. Zdaniem prelegenta modyfikacja ta była niezasadna i mogła prowadzić do nieporozumień, gdyż jedynym organem kompetentnym do wprowadzenia tych regulacji w życie było Ministerstwo Reform Rolnych ${ }^{48}$. Ostatecznie, rekomendowane przez wiceministra Raczyńskiego przywrócenie pierwotnego brzmienia omawianego art. 12. zostało przez posłów poparte w głosowaniu po trzecim czytaniu ${ }^{49}$.

Wnioski posłów Związku Parlamentarnego Polskich Socjalistów ${ }^{50}$ i Narodowej Partii Robotniczej ${ }^{51}$ przyczyniły się do procedowania w sejmie innego projektu ustawy socjalnej autorstwa klubów sejmowych, w którym brał udział przedstawiciel rządu. W ciągu trzech tygodni Komisja Ochrony Pracy zbadała dwa przedmiotowe projekty ustaw o zabezpieczeniu na wypadek bezrobocia, po czym 12 grudnia 1924 roku - w formie wystąpienia sprawozdawcy posła Jana Puchałki - przedstawiła swoje stanowisko sejmowi ${ }^{52}$.

Udział w debacie sejmowej wziął wiceminister skarbu Bolesław Markowski, który odrzucił propozycję wnioskodawców, aby nie stosować granicy w długości udzielania zasiłku dla bezrobotnych. Zdaniem przedstawiciela rządu mimo zrozumiałych intencji na taki postulat w ówczesnej chwili nie można było sobie pozwolić, głównie ze względu na stan finansów publicznych. Wobec tego wiceminister Markowski skutecznie - jak się później okazało - zaapelował do posłów, aby utrzymali maksymalny okres 26 tygodni w zakresie wypłacania omawianych świadczeń ${ }^{53}$.

Ostatnia warta odnotowania sprawa regulowana przez posłów, w której procedowaniu w sejmie wziął udział przedstawiciel drugiego gabinetu Grabskiego, dotyczyła nowelizacji ustawy o policji państwowej. 25 lutego 1925 roku do izby niższej parlamentu wpłynął odnośny wniosek posła Andrzeja Walerona z Polskiego Stronnictwa Ludowego „Wyzwolenie" ${ }^{54}$.

ustawy z dnia 2 lipca 1920 r. (Dz.U. z 1920 r., nr 56, poz. 346) oraz ustawy z dnia 18 marca 1920 r. (Dz.U. z 1920 r., nr 28, poz. 165).

${ }^{48}$ Sejm II RP, I kad., Spr. Sten. 138. pos. z 27 VI 1924, ł. 69 i n.

49 Ibidem, 1. 83; Ustawa z dnia 31 lipca 1924 r. w przedmiocie ochrony drobnych dzierżawców rolnych, a w szczególności zmiany niektórych przepisów ustawy z dnia 2 lipca 1920 r. oraz ustawy z dnia 18 marca 1920 r. (Dz.U. z 1924 r., nr 75, poz. 741).

${ }^{50}$ Sejm II RP, I kad., Druk nr 1538, Wniosek posłów Bronisława Ziemięckiego, Antoniego Szczerkowskiego i towarzyszy ze Związku Parlamentarnego Polskich Socjalistów w sprawie zmiany ustawy z dnia 18 lipca 1924 r. o zabezpieczeniu na wypadek bezrobocia (Dz.U. z 1924 r., nr 67 poz. 650).

${ }^{51}$ Sejm II RP, Druk nr 1570, Wniosek posła Jana Brzezińskiego i kolegów z Klubu Narodowej Partii Robotniczej w sprawie noweli do ustawy z dnia 18 lipca 1924 r. o zabezpieczeniu na wypadek bezrobocia (Dz.U. z 1924 r., nr 67, poz. 650).

${ }_{52}$ Sejm II RP, I kad., Spr. Sten. 169. pos. z 12 XII 1924, 1. 46-49.

${ }^{53}$ Ibidem, ł. 58. Ustawa $\mathrm{z}$ dnia 28 stycznia 1925 r. w przedmiocie zmiany art. 13 ustawy z dnia 18 lipca 1924 r. o zabezpieczeniu na wypadek bezrobocia, art. 1 (Dz.U. z 1925 r., nr 15, poz. 97).

${ }^{54}$ Sejm II RP, Druk nr 1769, Wniosek posła Andrzeja Walerona i kolegów z Klubu Związku Polskich Stronnictw Ludowych „Wyzwolenie” i „Jedność Ludowa” w przedmiocie nowelizacji ustawy z dnia 24 lipca 1919 r. o policji państwowej. 
16 lipca 1925 roku w sejmie zainicjowano drugie czytanie projektu ustawy, w trakcie którego przemawiał wiceminister skarbu Bolesław Markowski. Zapowiedział on posłom, że rząd jest skłonny do wprowadzenia zmian w dotychczasowym prawie, ale tylko tych racjonalnych. Stanowczo odrzucił tym samym możliwość poparcia wniosków poselskich zmierzających do całkowitego zdjęcia odpowiedzialności finansowej władz samorządowych za działania służb porządkowych. Jak bowiem mówił, ,stoimy na stanowisku, że pewna część kosztów utrzymania policji państwowej musi być włożona na samorządy; nie w tym ustosunkowaniu, jak obecnie to jest czynione, bo podział kosztów jest niesprawiedliwy i musi być zrobiony w słuszniejszy sposób, w każdym razie udział samorządów musi być zachowany"55. Jak się okazało, wspomniana debata zaowocowała uchwaleniem kilka dni później procedowanego projektu nowelizacji ${ }^{56}$.

Podsumowując powyższe treści, zauważyć można, że opisywane wystąpienia członków drugiego rządu Władysława Grabskiego w ramach sejmowej procedury czytań projektów ustaw miały dwojaki charakter. Po pierwsze, niektóre z nich były równoznaczne z zaprezentowaniem stanowiska gabinetu $\mathrm{w}$ odniesieniu do określonych propozycji uregulowań prawnych. Tym samym cechowało je kompleksowe i zarazem merytoryczne ujęcie zagadnień poruszanych w danym wniosku, częstokroć uzupełnione konkretnymi danymi liczbowymi. Po drugie, istotą części wystąpień członków rządu było wyjaśnienie i sprostowanie danych informacji lub polemika z przedmówcami - posłami uczestniczącymi w debacie plenarnej.

Analizując częstotliwość zabierania głosu przez ministrów na sali sejmowej podczas procedowania projektów ustaw, można dostrzec prawidłowość, że to przede wszystkim rządowe propozycje stanowiły przedmiot wyjaśnień ministrów. Projekty poselskie i klubowe były natomiast debatowane $\mathrm{z}$ udziałem przedstawicieli rządu w dużo mniejszym stopniu. W ciągu niespełna dwuletniego drugiego premierostwa Grabskiego doliczono się zaledwie 12 tego rodzaju wystąpień.

Warto również w podsumowaniu odnotować, że zdecydowana większość przemówień premiera Władysława Grabskiego i ministrów jego drugiego rządu (nade wszystko przedstawicieli Ministerstwa Skarbu) dotyczyła projektów ustaw, które wybitnie łączyły się z finansami publicznymi. Nie powinno to dziwić, zważywszy na specyfikę tego gabinetu (pozaparlamentarny rząd techniczny) oraz jego misję i podstawowe cele (szeroko rozumiane reformy gospodarcze, w tym sanacja Skarbu Państwa).

${ }_{55}^{55}$ Sejm II RP, Spr. Sten. 236. pos. z 16 VII 1925, 37 i n.

${ }^{56}$ Ustawa z dnia 22 lipca 1925 r. w przedmiocie zmiany ustawy z dnia 24 lipca 1919 r. o policji państwowej (Dz.U. z 1925 r., nr 83, poz. 565). 


\section{BIBLIOGRAFIA}

\section{Źródła}

Sejm II RP, I kadencja, Druki, Biblioteka Sejmowa, https://bs.sejm.gov.pl/F?func=file\&file name=find-nowe-2rp-sejm\&local_base=ars01 [dostęp: 20.02.2017].

Sejm II RP, I kadencja, Regulamin obrad Sejmu uchwalony 16 II 1923 r., uzupełniony zgodnie z uchwałami Sejmu z dnia 11 X 1923 r., 30 XI 1923 r., 14 XI 1924 r. i 18 XII 1924 r. wraz ze skorowidzem rzeczowym do regulaminu i Konstytucją Rzeczypospolitej Polskiej, art. 47, Biblioteka Sejmowa, https://bs.sejm.gov.pl/F?func=file\&file_name=find-nowe-2rp-sejm\&local_base=ars01 [dostęp: 20.02.2017].

Sejm II Rzeczypospolitej, I kadencja, Sprawozdania Stenograficzne z posiedzeń, Biblioteka Sejmowa, https://bs.sejm.gov.pl/F?func=file\&file_name=find-nowe-2rp-sejm\&local_ base $=\operatorname{ars} 01$ [dostęp: 20.02.2017].

Ustawa z dnia 11 stycznia 1924 r. o naprawie Skarbu Państwa i reformie walutowej (Dz.U. z 1924 r., nr 4, poz. 28).

Ustawa z dnia 15 lipca 1925 r. o państwowym podatku przemysłowym (Dz.U. z 1925 r., nr 79, poz. 550).

Ustawa z dnia 17 lipca 1924 r. w sprawie opłat za paszporty na wyjazd za granicę (Dz.U. z 1994 r., nr 69, poz. 672).

Ustawa z dnia 20 lipca 1925 r. o uzupełnieniu rozporządzenia Prezydenta Rzeczypospolitej z dnia 17 marca 1924 r. o przerachowaniu zobowiązań Skarbu Państwa z tytułu pożyczek państwowych oraz konwersji rzeczonych pożyczek oraz rozporządzenia Prezydenta Rzeczypospolitej z dnia 28 grudnia 1924 r. (Dz.U. z 1925 r., nr 90, poz. 629).

Ustawa z dnia 22 lipca 1925 r. w przedmiocie zmiany ustawy z dnia 24 lipca 1919 r. o policji państwowej (Dz.U. z 1925 r., nr 83, poz. 565).

Ustawa z dnia 28 stycznia 1925 r. w przedmiocie zmiany art. 13 ustawy z dnia 18 lipca 1924 r. o zabezpieczeniu na wypadek bezrobocia (Dz.U. z 1925 r., nr 15, poz. 97).

Ustawa z dnia 31 lipca 1924 r. o naprawie Skarbu Państwa i poprawie gospodarstwa społecznego (Dz.U. z 1924 r., nr 71, poz. 687).

Ustawa z dnia 31 lipca 1924 r. w przedmiocie ochrony drobnych dzierżawców rolnych, a w szczególności zmiany niektórych przepisów ustawy z dnia 2 lipca $1920 \mathrm{r}$. oraz ustawy z dnia 18 marca 1920 r. (Dz.U. z 1924 r., nr 75, poz. 741).

\section{Opracowania}

Ajnenkiel A., Historia sejmu polskiego, t. 2, cz. 2, Warszawa 1989.

A jnenki el A., Od rządów ludowych do przewrotu majowego. Zarys dziejów politycznych Polski 1918-1926, Warszawa 1977.

Drozd ow ski M.M., Władysław Grabski, Rzeszów-Warszawa 2004.

Fron c zek-Kwarta A., Polityka finansowa i gospodarcza rządu Władysława Grabskiego w okresie reformy walutowo-skarbowej (1923-1925), Poznań 2014.

Go fron P., Ustawy o nadzwyczajnych petnomocnictwach dla prezydenta Rzeczpospolitej w 1924 roku [w:] O ksztalt Rzeczpospolitej. Studia z zakresu polskiej myśli politycznej i ustrojowej okresu międzywojennego, red. P. Go fro n, A. Pa derew s ka, A. Matuła, Kraków 2016, s. 145-160. 
Gołębiowski J., Grabski Władysław [w:] Kto byt kim w Drugiej Rzeczypospolitej, red. J.M. Maj c hrow ski, Warszawa 1994, s. 40.

Jaki el J., Gabinet Władystawa Grabskiego. 19 XII 1923-13 XI 1925 [w:] Gabinety Drugiej Rzeczypospolitej, red. J. F ary ś, J. P aj e w s k i, Szczecin-Poznań 1991, s. 123-138.

Jakiel J., Grabski Władystaw [w:] Ministrowie Polski Niepodległej 1918-1945, red. M. B a u m gart, H. Wa lc zak, A. W ą tor, Szczecin 2001, s. 124-129.

Ministrowie gabinetów Polski Niepodległej. 19 XII 1923-14 XI 1925 [w:] Ministrowie Polski Niepodległej 1918-1945, red. M. B a umgart, H. Walczak, A. W ą tor, Szczecin 2001, s. 25 i n.

Moraw ski W., Władysław Grabski - polityk, mąż stanu, reformator, Warszawa 2004.

Morawski W., Władystaw Grabski, premier rzadu polskiego 23 VI-24 VII 1920, 19 XII 1923-14 XI 1925 [w:] Prezydenci i premierzy Drugiej Rzeczypospolitej, red. A. Chojnow ski, P. Wróbe1, Wrocław 1992, s. 121-134.

P i trzak M., Rzady parlamentarne w Polsce w latach 1919-1926, Warszawa 1969.

Piwarski K., Grabski Władysław (1874-1938) [w:] Polski Słownik Biograficzny, t. 8, red. K. Le p s zy, Wrocław 1960, s. 524-528.

Skodlarski J., Władysław Grabski jako ekonomista (1874-1938), Łódź 2015. 